\title{
KUALITAS PRODUK PERALATAN PERTANIAN HASIL TEMPA PANAS PENGRAJIN PANDE BESI MELALUI PENERAPAN DESAIN DAPUR PERLAKUAN PANAS MODEL TUTUP
}

\author{
Djoko Andrijono, Sufiyanto \\ Program Studi Teknik Mesin Fakultas Teknik Universitas Merdeka Malang \\ Jalan Taman Agung No. 1 Malang \\ Email: djoko.andrijono@unmer.ac.id, sufiyanto@unmer.ac.id
}

\begin{abstract}
The problems encountered by artisan blacksmiths based on the field study results: unable to detect incineration temperature of wood charcoal in the crucibles, crusts occurrence on the metal surface of scrap component of spring leaf SUP 9 after heating process in the exposed model heating treatment. The solutions taken were by transforming the kitchen design, from exposed model heating treatment to closeted model heating treatment, which aimed to avoid oxidation on the incinerated metal, thus crusts do not occur on its surface. The kitchen wall of closeted model heating treatment was made from fireproof bricks, held heat resistance, and carried a stable thermal conductivity out of wood charcoal incineration. A digital thermocouple was installed in the closeted model heating treatment kitchen to accurately measure the temperature of wood charcoal incineration results. The closeted heating model treatment kitchen was designed portable. The solution methods applied field study and descriptive analysis. The study generated a result of sturdiness value with $18.8 \mathrm{HR}_{\mathrm{C}}$ average for hoe products was below the standard of sturdiness value according to SNI 02-0331-1989 and generated a result of kitchen wall of closeted model heating treatment made from red bricks with cement as the fastener could not stand the heat. The conclusion for the application of kitchen design of closeted model heating treatment were the sturdity values achieved $58 \mathrm{HR}_{\mathrm{C}}$ with $\mathrm{SAE} 90^{\circ} \mathrm{C}$ as the cooling lube and the wear rate achieved $0.000165605 \mathrm{gram} / \mathrm{m}$. This meant the wear resistance property was low which met the standard according to SNI 02-0331-1989.
\end{abstract}

Key Words: Artisan blacksmith: scrap steel; heating treatment kitchen; sturdity

\begin{abstract}
Abstrak
Permasalahan pengrajin pande besi sesuai hasil studi lapangan: temperatur pembakaran arang kayu di dalam kowi tidak dapat dideteksi, permukaan logam bekas kompoen pegas daun SUP 9 timbul kerak setelah proses pemanasan di dalam dapur perlakuan panas model buka. Metode pemecahannya melakukan inovasi pada desain dapur perlakuan panas model buka dirubah menjadi desain dapur perlakuan panas model tutup yang bertujuan: material logam yang dipanasi tidak teroksidasi, sehingga permukaan logam tidak timbul kerak, dinding dapur perlakuan panas model tutup terbuat dari bata tahan api, mempunyai sifat tahan panas serta konduktivitas panas hasil pembakaran arang kayu stabil, dapur perlakuan panas model tutup dipasang termokopel digital agar temperatur hasil pembakaran arang kayu terukur dan akurat, dan dapur perlakuan panas model tutup dirancang dapat dipindah-pindah tempat. Metode pemecahannya menggunakan metode studi lapangan dan metode analisis deskriptif. Hasil-hasil temuan yang diperoleh angka kekerasan produk cangkul rata-rata 18,8 HR $R_{C}$ masih di bawah angka kekerasan cangkul menurut SNI 02-0331-1989, dinding dapur perlakuan panas model buka terbuat bata merah dengan pengikat semen tidak tahan panas. Simpulan dengan penerapan desain dapur perlakuan panas model tutup, angka kekerasan mencapai $58 H R_{C}$ dengan media pendinginan oli SAE 90 dan laju keausan $0.000165605 \mathrm{gram} / \mathrm{m}$ memenuhi SNI 02-0331-1989, sehingga sifat ketahanan ausnya rendah.
\end{abstract}

Kata Kunci: pengrajin pande besi; baja bekas; dapur perlakuan panas; kekerasan 


\section{PENDAHULUAN}

\section{Kajian Literatur Terdahulu}

Proses tempa merupakan proses pembentukan dengan cara ditempa panas dan tempa dingin menggunakan cetakan serta gaya penempaan yang berasal: palu, listrik dan hidrolis sampai membentuk produk. Aplikasi proses tempa untuk pembuatan: a) bagianbagian traktor, b) galangan kapal, c) komponen kereta api, d) mesin-mesin pertanian. Logam yang dapat ditempa meliputi: a) baja karbon rendah, b) baja karbon menengah, c) baja karbon paduan, d) paduan dasar tembaga, e) paduan alumunium, f) paduan magnesium, g) baja tahan karat, dan h) titanium

Keuntungan proses tempa meliputi: a) komponen hasil tempa memiliki sifat keuletan yang tinggi, b) proses penempaan dapat memurnikan struktur logam, c) proses penempaan hemat waktu, tenaga kerja, dan d) proses penempaan mendistorsi serat yang tidak beraturan arah, e) tingkat kepresisian yang tinggi dapat diperoleh dalam operasi penempaan, dan f) bagian yang ditempa dapat dengan mudah dilas. Kerugian proses tempa meliputi: a) oksidasi yang cepat dalam penempaan permukaan logam pada suhu tinggi menghasilkan kerak, b) proses penempaan terbatas pada bentuk produk yang sederhana, c) beberapa logam tidak dapat dikerjakan dengan proses tempa, d) logam yang ditempa menjadi retak jika bekerja di bawah batas temperatur tertentu, dan e) perawatan cetakan tinggi.

\section{Kebaruan Ilmiah}

Produk torak dengan proses tempa dapat meningkatkan angka kekerasan rata-rata lebih tinggi $14,9 \%$ dari 121,1 HV dibanding torak hasil cor. Torak hasil proses tempa terjadi deformasi yang menyebabkan pengerasan regang dan memiliki struktur mikro yang homogen, sedangkan torak hasil cor memiliki struktur dendrite, sehingga memiliki kekuatan yang lebih tinggi dibanding torak hasil cor. Produk alat potong dengan proses tempa dengan metode flame hardening dapat meningkatkan kekerasan hasil tempa dengan material baja karbon menengah, sehingga menghasilkan kekerasan tertinggi $866 \mathrm{HV}$ di daerah ujung serta memiliki struktur mikro martensit dan ferit $\left(\alpha+\mathrm{Fe}_{3} \mathrm{C}\right)$

Metode meningkatkan sifat kekerasan dengan pack carburizing pada pembuatan cangkul dapat meningkatkan nilai kekerasan ditandai dengan meningkatnya persentase kandungan karbon material cangkul. Angka kekerasan cangkul hasil peningkatan mutu telah memenuhi standar nilai SNI 02-0331-1989 KW III yaitu bernilai ratarata $39 \mathrm{HR}_{\mathrm{C}}$. Nilai ini dicapai pada media pack carburizing jenis arang kayu albasia dengan media pendinginan cepat. Untuk persentase unsur karbon material cangkul meningkat dari $0,21 \%$ pada material awal sebelum pack carburizing menjadi $1,33 \%, 1,38 \%$ dan $1,42 \%$.

Proses tempa panas pengrajin pande besi berorientasi pada pembuatan peralatan pertanian dengan cara memanaskan material logam bekas (Gambar 1) pada dapur perlakuan panas 
model buka menggunakan arang kayu. Kondisi pemanasan logam yang terjadi cenderung masih di bawah temperatur rekristalisasi dan selanjutnya ditempa di atas landasan (Gambar 2) yang berfungsi sebagai cetakan.

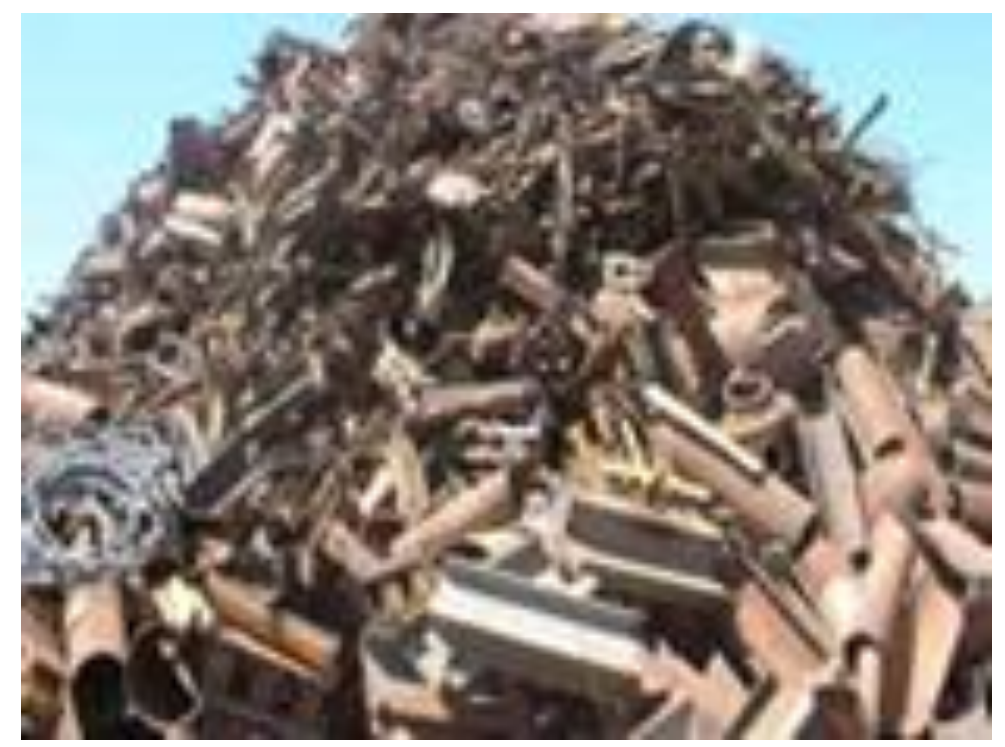

Gambar 1. Limbah Material Logam Bekas

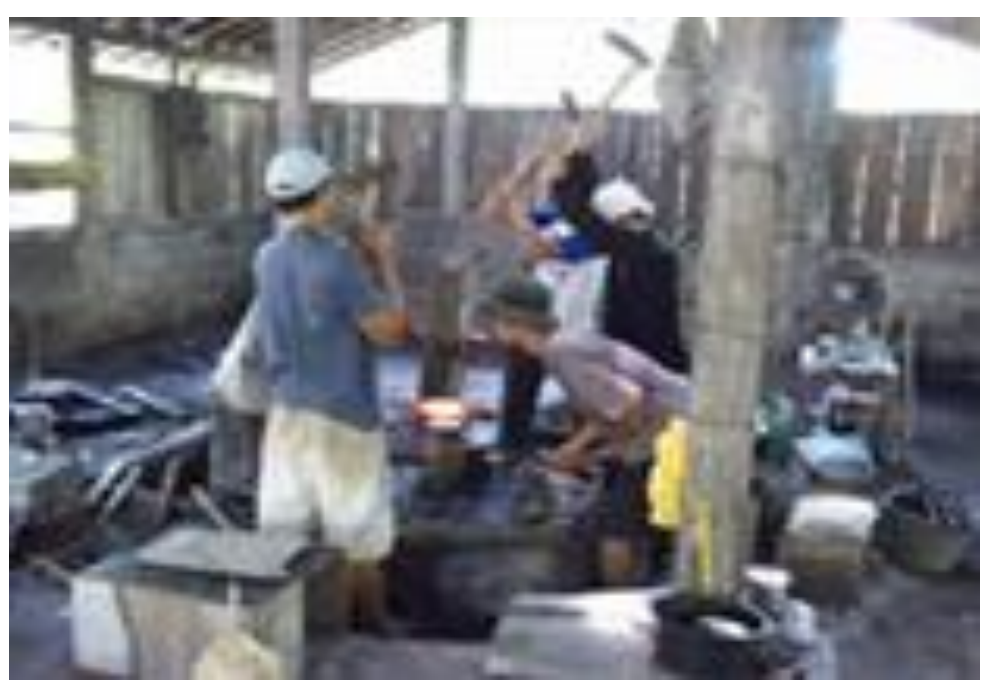

Gambar 2. Proses Tempa Manual di atas Landasan

\section{Permasalahan Pengrajin Pande Besi} atau Hipotesis

Hasil studi lapangan ditemukan beberapa permasalahan antara lain: a) temperatur hasil pembakaran arang kayu tidak dapat dideteksi, b) permukaan logam setelah ditempa bekas timbul kerak setelah proses pemanasan di dalam dapur perlakuan panas terbuka, dan c) produk pengrajin pande besi, khususnya jenis cangkul angka kekerasan rata-rata 18,8 $\mathrm{HR}_{\mathrm{C}}$ di bawah angka kekerasan cangkul menurut SNI 02-0331-1989 (Tabel 1). 
Tabel 1. Klasifikasi Angka Kekerasan Cangkul

\begin{tabular}{|c|c|c|c|c|}
\hline No & Kelas & $\begin{array}{c}\text { Kekerasan } \\
\left(\mathbf{H R}_{\mathrm{C}}\right)\end{array}$ & Aplikasi & $\begin{array}{c}\text { Konstruksi Sambungan Lubang Gagang } \\
\text { dengan Daun }\end{array}$ \\
\hline 1 & I & $55-59$ & Tanah keras & Ditempa secara kesatuan atau dilas \\
\hline 2 & II & $48-54$ & $\begin{array}{l}\text { Tanah setengah } \\
\text { keras }\end{array}$ & Ditempa secara kesatuan, dilas atau dikeling \\
\hline 3 & III & $30-47$ & Tanah lunak & $\begin{array}{l}\text { Ditempa secara kesatuan, dilas kering atau } \\
\text { disambung tempa. }\end{array}$ \\
\hline
\end{tabular}

Sumber: Standar Industri Indonesia "Mutu dan Cara Uji Cangkul"

\section{TINJAUAN LITERATUR}

Pemberdayaan

masyarakat

merupakan upaya atau proses untuk menumbuhkan kesadaran, kemauan, dan kemampuan masyarakat dalam mengenali, mengatasi, memelihara, serta meningkatkan kesejahteraan (Gambar 3). Tujuan pemberdayaan masyarakat: a) perbaikan kelembagaan, b) perbaikan usaha, c) perbaikan pendapatan, d) perbaikan lingkungan, e) perbaikan kehidupan, dan d) perbaikan masyarakat.

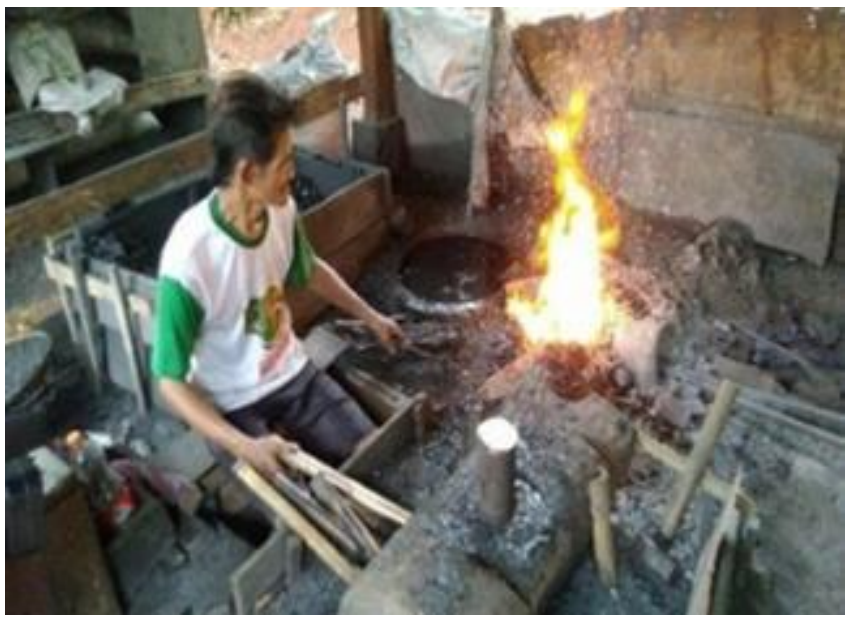

Gambar 3. Pemberdayaan Masyarakat bagi Pengrajin Pande Besi

Beberapa prinsip pemberdayaan masyarakat pada program pemberdayaan meliputi: a) kesetaraan, b) partisipasi, c) keswadayaan atau kemandirian dan berkelanjutan. Cara melakukan pemberdayaan masyarakat dengan 3 (tiga) pendekatan: a) pengembangan masyarakat, b) pengorganisasian masyarakat, dan c) perubahan perilaku masyarakat. Pada penerapan desain dapur perlakuan panas model tutup, pemberdayaan masyarakat menggunakan prinsip partisipasi dengan cara merubah perilaku masyarakat, khususnya pengrajin pande besi dalam penguasaan teknologi dan memahami: a) proses pemilihan dan sifat material untuk pembuatan dapur perlakuan panas, b) proses pemilihan material yang akan ditempa, c) pemilihan jenis arang kayu, d) menentukan temperatur pemanasan, 
e) cara melakukan proses tempa dan f) pemilihan media pendinginan.

\section{METODE PELAKSANAAN} Pemecahan Permasalahan

Mengatasi permasalahan di atas, perlu dilakukan inovasi dapur perlakuan panas model buka milik pengrajin pande besi diubah dengan desain dapur perlakuan panas model tutup (Gambar 7). Adapun tujuan desain inovasi antara lain: a) material logam yang dipanasi tidak teroksidasi, sehingga permukaan material tidak timbul kerak, b) dinding dapur perlakuan panas model tutup terbuat dari bata tahan api, tidak mudah retak dan pecah serta konduktivitas panas hasil pembakaran arang kayu stabil, c) dapur perlakuan panas model tutup dipasang termokopel digital agar temperatur hasil pembakaran arang kayu terukur dan akurat, dan d) dapur perlakuan panas model tutup dirancang dapat dipindah-pindah tempat (portable furnace).

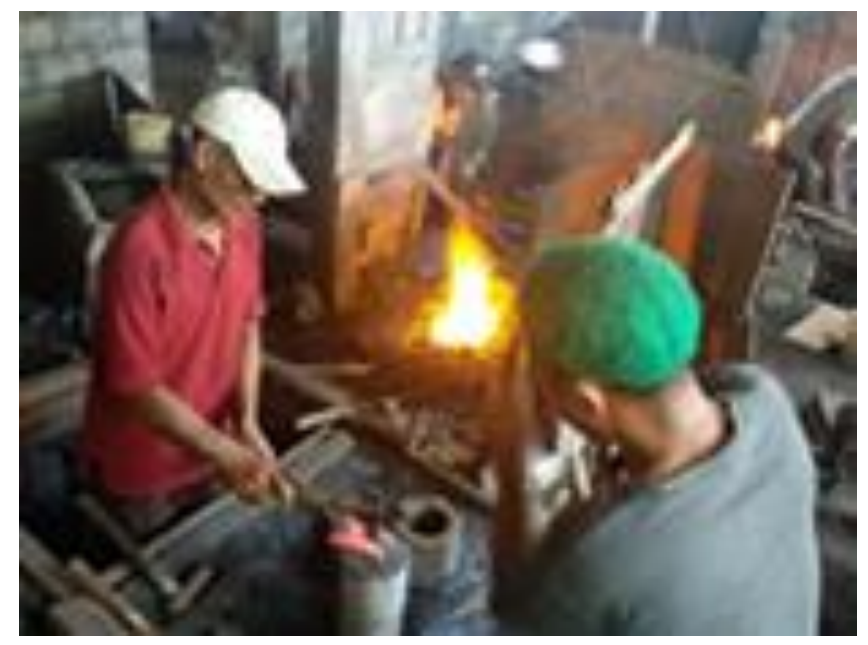

Gambar 4. Desain Dapur Perlakuan Panas Terbuka

Dapur perlakuan panas model buka memiliki keuntungan meliputi: a) pengoperasian dapur perlakuan panas terbuka tidak membutuhkan keahlian khusus tetapi ketrampilan yang lebih diutamakan, dan b) bahan bakar arang kayu tersedia di pasaran dan harganya murah. Kelemahan dapur perlakuan panas model buka meliputi: a) temperatur hasil pembakaran arang kayu tidak stabil, b) permukaan logam yang dipanasi mudah teroksidasi, akibatnya timbul kerak, c) logam bekas komponen pegas daun SUP 9 yang ditempa tidak teridentifikasi jenis logamnya dan komposisi kimia.

\section{Metode-Metode yang Digunakan dalam Penyelesaian Pengabdian Masyarakat}

Sebelum melakukan analisis, dilakukan: a) observasi untuk melakukan pengamatan langsung dan mencatat data-data teknis dan non teknis kondisi dapur perlakuan panas terbuka, dan b) wawancara untuk memperoleh informasi terkait dengan jenis arang kayu, jenis material logam dan media pendinginan 
yang dipakai. Metode analisis yang digunakan analisis deskriptif bertujuan untuk memberikan gambaran yang terkait data-data hasil observasi dan wawancara berupa data teknis dan non teknis untuk dilakukan inovasi dari desain dapur perlakukan panas terbuka diubah menjadi dapur perlakuan panas model tutup dengan tahapan-tahapan sebagai berikut:

a. Tahapan Menggambar Lay Out Desain Perlakuan Panas Model Tutup

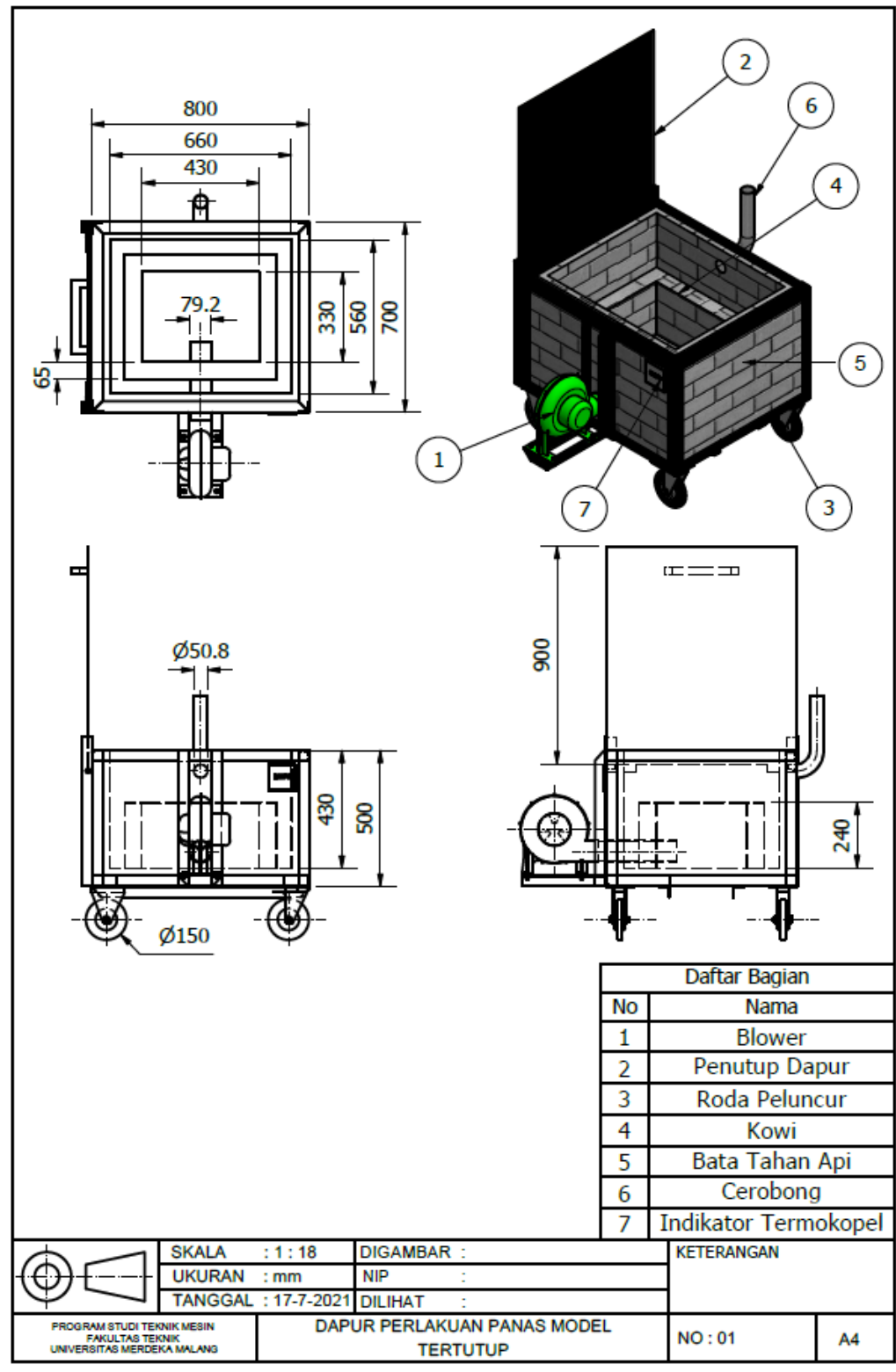

Gambar 5. Lay Out Dapur Perlakuan Panas Model Tutup

b. Tahapan Pelaksanaan Inovasi

Pembuatan Dapur Perlakuan Panas

Model Tutup 


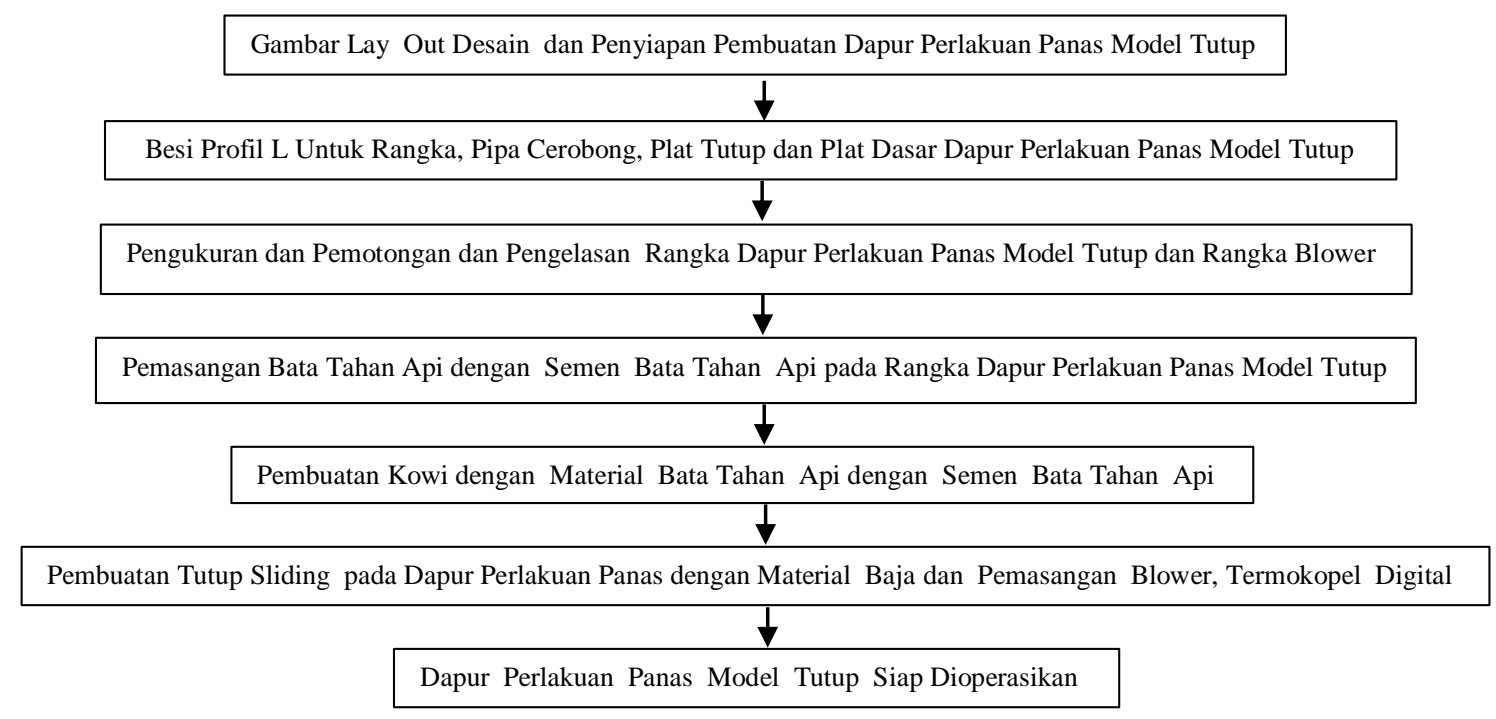

Gambar 6. Tahapan Pelaksanaan Inovasi Pembuatan Dapur Perlakuan Panas Model Tutup

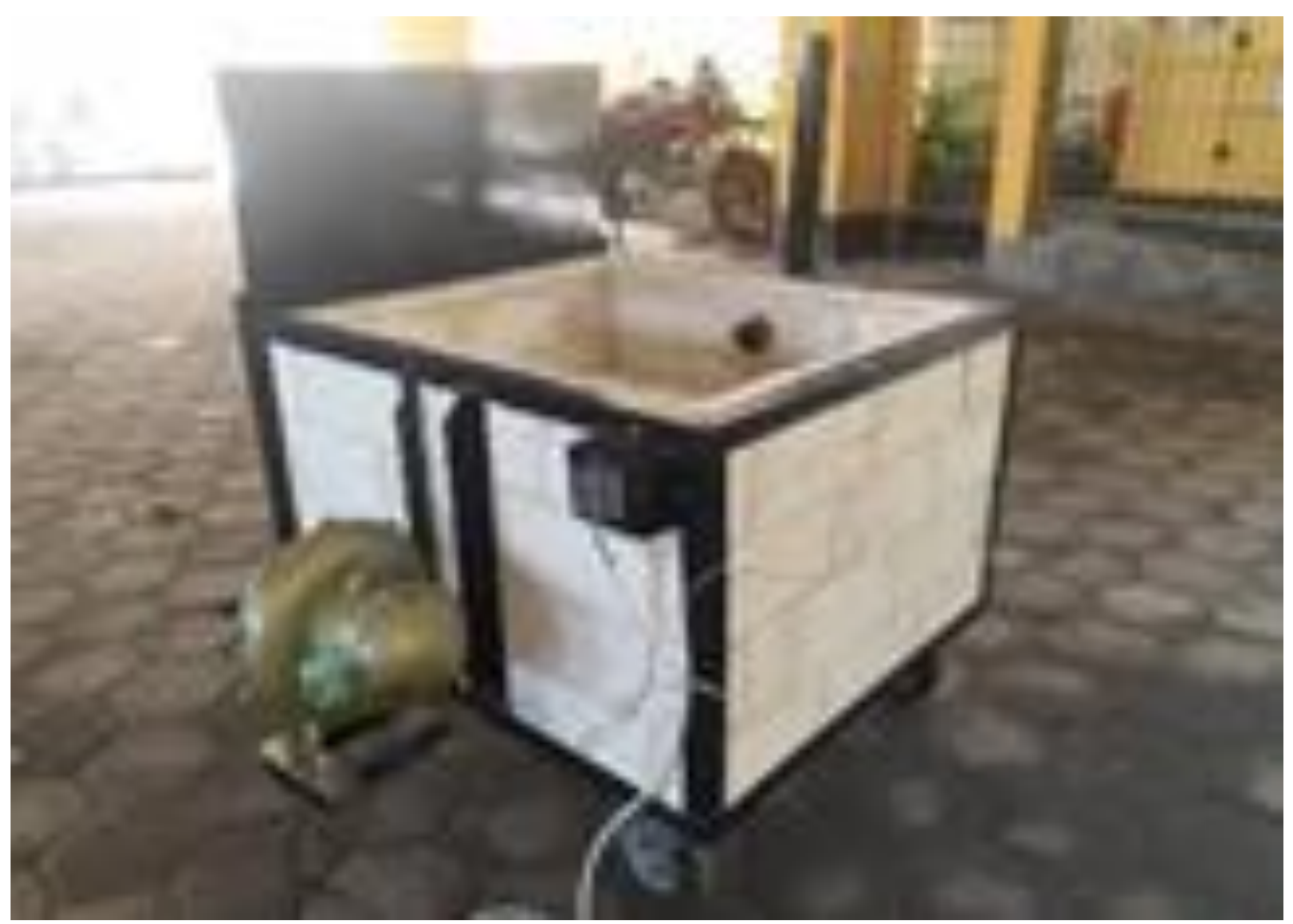

Gambar 7. Hasil Inovasi Desain Dapur Perlakuan Panas Model Tutup

c. Tahapan Pelaksanaan Pengoperasian

Penerapan Desain Dapur Perlakuan

Panas Model Tutup 


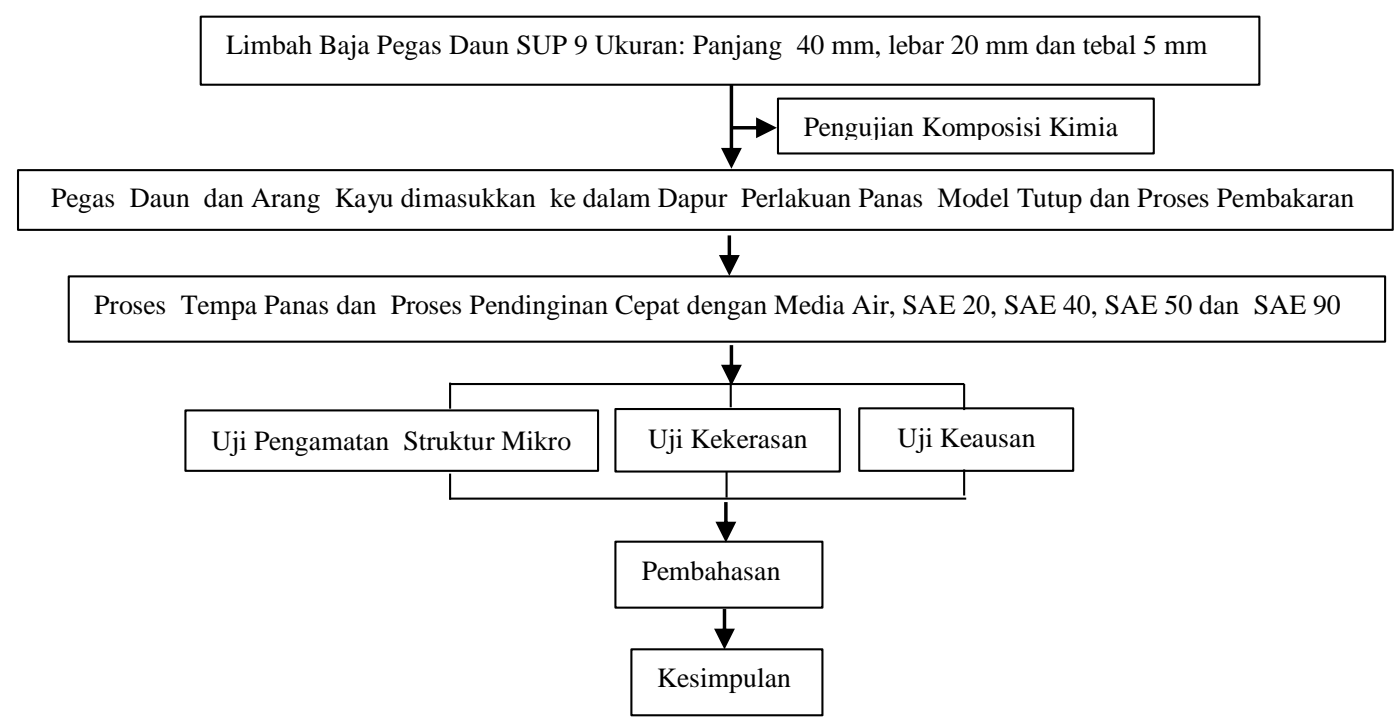

Gambar 8. Tahapan Pelaksanaan Pengoperasian Penerapan Desain Dapur Perlakuan Panas Model Tutup

4. HASIL DAN PEMBAHASAN Data Hasil Pelaksanaan Uji Komposisi Kimia

Material yang digunakan oleh pengrajin pande besi jenis baja bekas komponen pegas daun SUP 9. Material tersebut, sebelum ditempa panas dan proses pendinginan cepat: air, SAE 20, SAE 40, SAE 50, SAE 90 diawali uji komposisi kimia menggunakan mesin Quantometer 3460/MA (Gambar 9) dan hasil data hasil pelaksanaan uji komposisi kimia (Tabel 2).

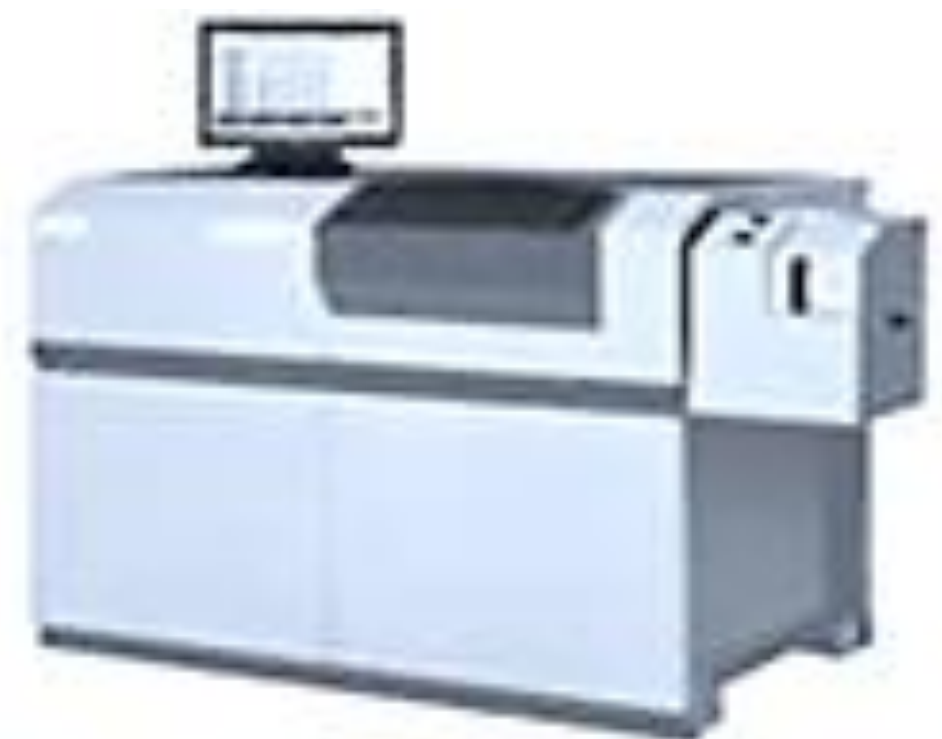

Gambar 9. Mesin Quantometer 3460/MA 
Tabel 2. Data Hasil Uji Komposisi Kimia Baja Bekas Komponen Pegas Daun SUP 9 sebelum Proses Tempa Panas

\begin{tabular}{lcccccc}
\hline Unsur Kimia & $\mathrm{C}$ & $\mathrm{Mn}$ & $\mathrm{P}$ & $\mathrm{S}$ & $\mathrm{Si}$ & $\mathrm{Sn}$ \\
\hline $\begin{array}{l}\text { Komposisi Kimia } \\
(\%)\end{array}$ & 0,5818 & 0,8878 & 0,0133 & 0,0055 & 0,2745 & 0,0052 \\
\hline Unsur Kimia & $\mathrm{Cr}$ & $\mathrm{Cu}$ & $\mathrm{Ni}$ & $\mathrm{Nb}$ & $\mathrm{V}$ & $\mathrm{Ca}$ \\
\hline $\begin{array}{l}\text { Komposisi Kimia } \\
(\%)\end{array}$ & 0,8636 & 0,0981 & 0,0475 & 0,0032 & 0,0051 & 0,0005 \\
\hline Unsur Kimia & $\mathrm{Co}$ & $\mathrm{B}$ & $\mathrm{N}$ & $\mathrm{Ti}$ & $\mathrm{Al}$ & $\mathrm{Mo}$ \\
\hline $\begin{array}{l}\text { Komposisi Kimia } \\
(\%)\end{array}$ & 0,0121 & 0,00015 & 0,0073 & 0,0014 & 0,0065 & 0,0224 \\
\hline
\end{tabular}

\begin{tabular}{|c|c|c|}
\hline $\begin{array}{l}\text { ata Hasil } \\
\text { ekerasan }\end{array}$ & Pelaksanaan & $\begin{array}{l}\text { pendinginan cepat seperti: air, SAE 20, } \\
\text { SAE 40, SAE 50, dan SAE } 90 \text { diuji } \\
\text { kekerasan menggunakan mesin Rockwell }\end{array}$ \\
\hline $\begin{array}{l}\text { Pelaksanaan } \\
\text { as komponen } \\
\text { lah ditempa }\end{array}$ & $\begin{array}{l}\text { uji kekerasan baja } \\
\text { pegas daun SUP } 9 \\
\text { panas dan proses }\end{array}$ & $\begin{array}{l}\text { Hardness Tester (Gambar 11) dan hasil } \\
\text { data hasil pelaksanaan uji kekerasan } \\
\text { (Tabel 3). }\end{array}$ \\
\hline
\end{tabular}

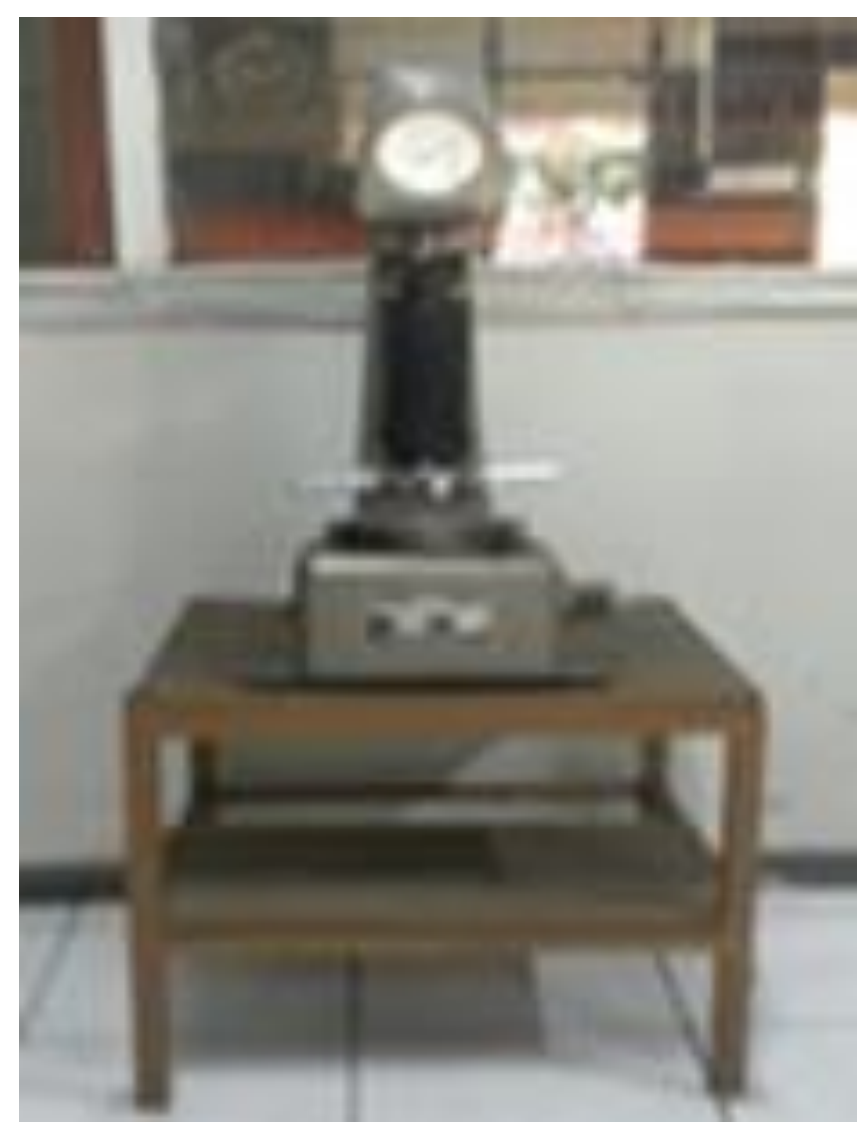

Gambar 11. Mesin Rockwell Hardness Tester 
Tabel 3. Data Hasil Uji Kekerasan Material Baja Bekas Komponen Pegas Daun SUP 9 Setelah Proses Tempa Panas $\mathrm{T}=500{ }^{\circ} \mathrm{C}$ dengan Variasi Media Pendinginan Cepat

\begin{tabular}{|c|c|c|c|c|c|c|c|}
\hline \multirow[t]{2}{*}{ No } & \multirow{2}{*}{$\begin{array}{c}\text { Suhu } \\
\text { Pemanasan } \\
\left({ }^{0} \mathrm{C}\right)\end{array}$} & \multirow{2}{*}{$\begin{array}{c}\text { Media } \\
\text { Pendinginan } \\
\text { Cepat }\end{array}$} & \multirow{2}{*}{$\begin{array}{c}\text { Kode } \\
\text { Spesimen } \\
\text { Uji }\end{array}$} & \multicolumn{3}{|c|}{$\begin{array}{c}\begin{array}{c}\text { Angka Kekerasan } \\
(\text { HRC })\end{array} \\
\text { Titik Pengujian }\end{array}$} & \multirow{2}{*}{$\begin{array}{c}\text { Rata-2 } \\
\text { Angka } \\
\text { Kekerasan } \\
\left(\text { HRC }^{2}\right)\end{array}$} \\
\hline & & & & 1 & 2 & 3 & \\
\hline 1 & 27 & Logam induk & PD 00 & 49 & 47 & 48 & 48 \\
\hline 2 & 500 & Air & PD 01 & 62 & 67 & 63 & 64 \\
\hline 3 & 500 & SAE 20 & PD 02 & 62,5 & 64 & 64 & 63,5 \\
\hline 4 & 500 & SAE 40 & PD 03 & 63 & 63 & 63,5 & 63,2 \\
\hline 5 & 500 & SAE 50 & PD 04 & 62 & 62 & 60 & 61,3 \\
\hline 6 & 500 & SAE 90 & PD 05 & 57 & 59 & 58 & 58 \\
\hline
\end{tabular}

\section{Data Hasil Pelaksanaan Uji Keausan}

Uji keausan baja bekas komponen pegas daun SUP 9 setelah ditempa panas dan proses pendinginan cepat: air, SAE
20, SAE 40, SAE 50, dan SAE 90 diuji menggunakan mesin uji keausan (gambar 12) dan data hasil pelaksanaan uji keausan (Tabel 4).

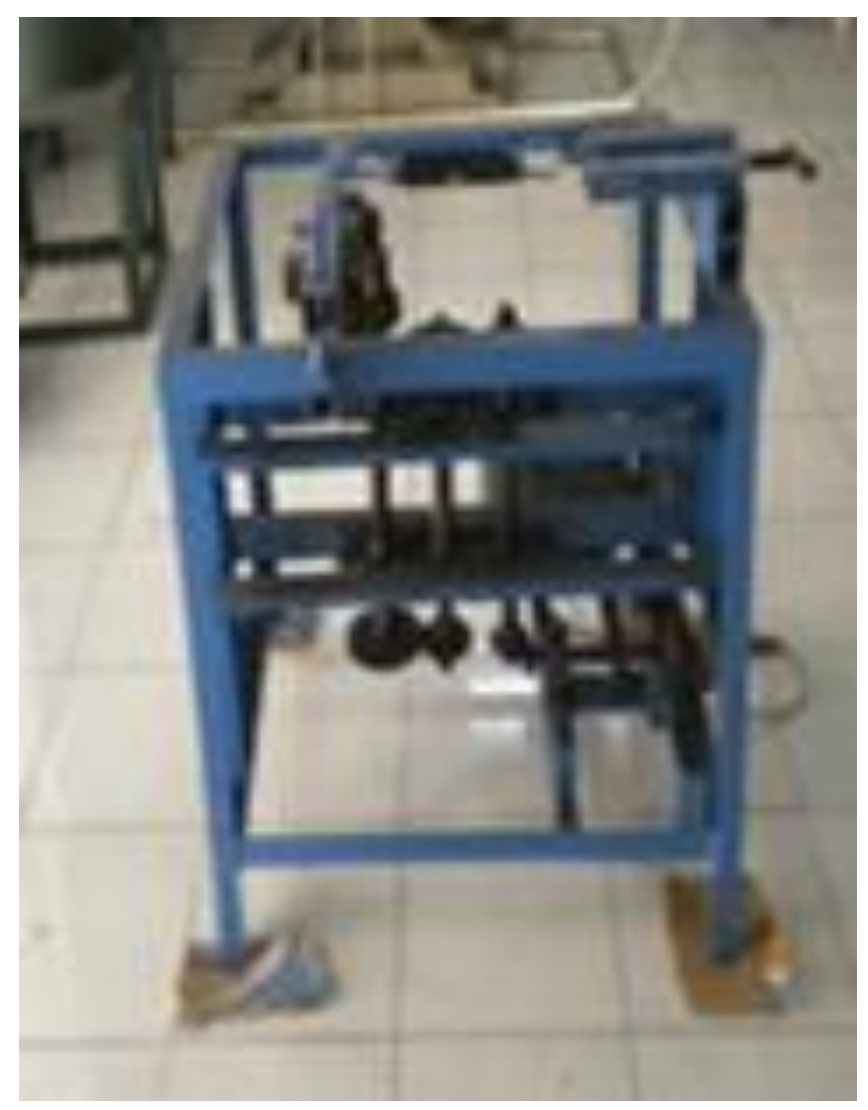

Gambar 12. Mesin Uji Keausan 
Tabel 4. Data Hasil Uji Keausan Material Baja Bekas Komponen Pegas Daun SUP 9 Setelah Proses Tempa Panas $\mathrm{T}=500{ }^{\circ} \mathrm{C}$ dengan Variasi Media Pendinginan Cepat

\begin{tabular}{|c|c|c|c|c|c|c|c|c|c|}
\hline \multirow{2}{*}{$\begin{array}{c}\text { Kode } \\
\text { Spesimen } \\
\text { uji } \\
\end{array}$} & \multirow{2}{*}{$\begin{array}{c}\text { Media } \\
\text { Pendinginan } \\
\text { Cepat }\end{array}$} & \multirow{2}{*}{$\begin{array}{c}\text { Beban } \\
(\mathbf{k g})\end{array}$} & \multirow{2}{*}{$\begin{array}{l}\text { Waktu } \\
\text { (menit) }\end{array}$} & \multicolumn{3}{|c|}{ Berat (gram) } & \multirow{2}{*}{$\begin{array}{c}\text { Kecepatan } \\
\text { Linier } \\
(\mathrm{m} / \mathrm{emenit}) \\
\end{array}$} & \multirow{2}{*}{$\begin{array}{c}\text { Jarak } \\
\text { Luncur } \\
\text { (m) }\end{array}$} & \multirow{2}{*}{$\begin{array}{c}\text { Laju } \\
\text { Keausan } \\
(\text { gram/m) }\end{array}$} \\
\hline & & & & Awal & Akhir & Hilang & & & \\
\hline PD 00 & Logam induk & 12 & 4 & 33.719 & 33.665 & 0.025 & 78.5 & 314 & 0.0000171975 \\
\hline PD 01 & Air & 12 & 4 & 13.380 & 13.347 & 0.033 & 78.5 & 314 & 0.000105096 \\
\hline PD 02 & SAE 20 & 12 & 4 & 12.786 & 12.752 & 0.034 & 78.5 & 314 & 0.000108280 \\
\hline PD 03 & SAE 40 & 12 & 4 & 16.191 & 16.156 & 0.035 & 78.5 & 314 & 0.000111465 \\
\hline PD 04 & SAE 50 & 12 & 4 & 15.931 & 15.881 & 0.050 & 78.5 & 314 & 0.000159236 \\
\hline PD 05 & SAE 90 & 12 & 4 & 13.627 & 13.575 & 0.052 & 78.5 & 314 & 0.000165605 \\
\hline
\end{tabular}

Data Hasil Pelaksanaan Uji SAE 40, oli SAE 50, oli SAE 90 Pengamatan Struktur Mikro menggunakan mesin uji mikroskop

Uji pengamatan struktur mikro logam (Gambar 13) dan data hasil baja bekas komponen pegas daun SUP 9 setelah ditempa panas dan proses pelaksanaan uji pengamatan struktur mikro (Tabel 5).

pendinginan cepat: air, oli SAE 20, oli

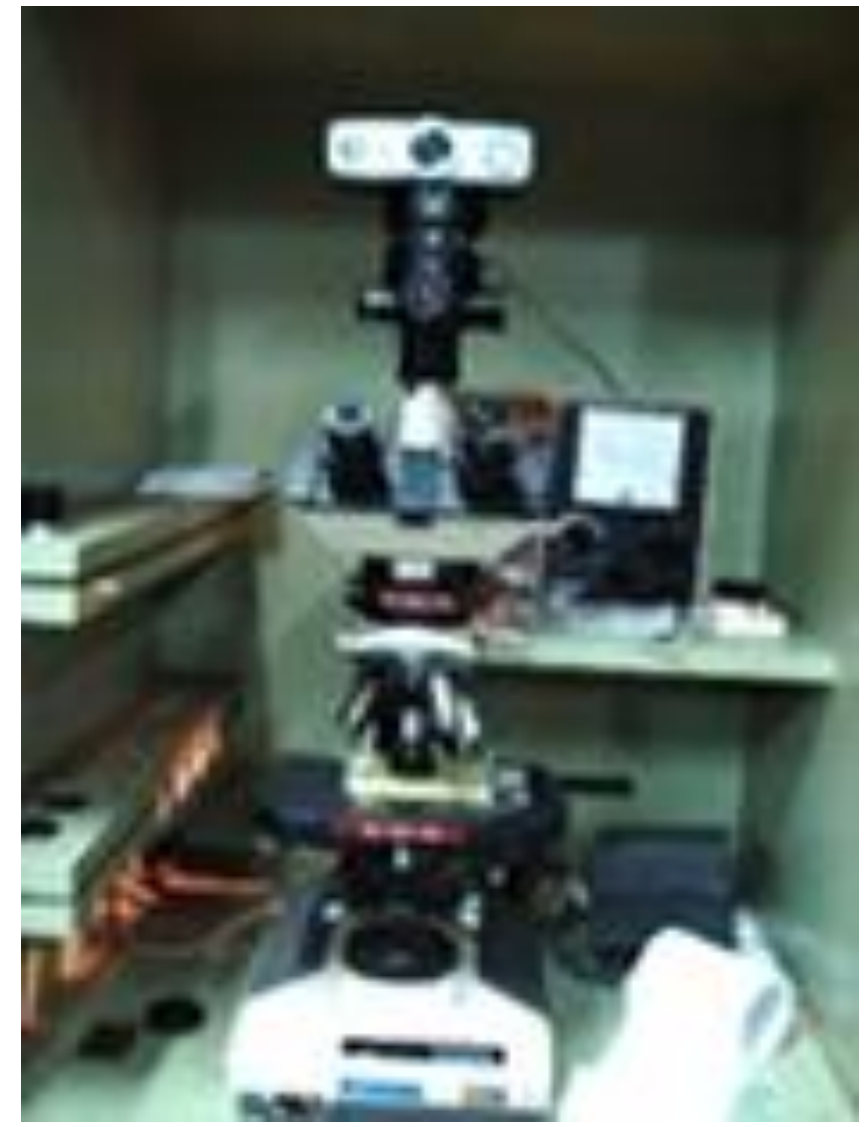

Gambar 13. Mikroskop Logam 
Tabel 5. Data Hasil Uji Pengamatan Struktur Mikro Material Baja Bekas Komponen Pegas Daun SUP 9 Setelah Proses Tempa Panas $\mathrm{T}=500{ }^{0} \mathrm{C}$ dengan Variasi Media Pendinginan Cepat

\begin{tabular}{|c|c|c|c|c|c|}
\hline $\begin{array}{c}\text { Kode } \\
\text { Spesimen Uji }\end{array}$ & $\begin{array}{c}\text { Media Pendinginan } \\
\text { Cepat }\end{array}$ & $\begin{array}{l}\text { Uji Pengamatan } \\
\text { Struktur Mikro }\end{array}$ & $\begin{array}{c}\text { Kode } \\
\text { Spesimen Uji }\end{array}$ & $\begin{array}{c}\text { Media Pendinginan } \\
\text { Cepat }\end{array}$ & $\begin{array}{l}\text { Uji Pengamatan } \\
\text { Struktur Mikro }\end{array}$ \\
\hline PD 00 & Logam induk & & PD 03 & SAE 40 & \\
\hline PD 01 & Air & & PD 04 & SAE 50 & \\
\hline PD 02 & SAE 20 & & PD 04 & SAE 50 & \\
\hline
\end{tabular}

\section{Pembahasan}

Hasil studi lapangan pada pengrajin pande besi, terdapat beberapa permasalahan seperti: a) temperatur hasil pembakaran arang kayu di ruang kowi tidak dapat dideteksi, b) permukaan logam bekas komponen pegas daun SUP 9 timbul kerak setelah proses pemanasan di dalam dapur perlakuan panas model buka, c) jenis logam bekas komponen pegas daun SUP 9 tidak teridentifikasi, dan d) produk pengrajin pande besi, khususnya jenis cangkul angka kekerasan rata-rata $18,8 \mathrm{HR}_{\mathrm{C}}$ masih di bawah angka kekerasan cangkul menurut SNI 02-0331-1989 (Tabel 1). Untuk mengatasi permasalahan di atas, dilakukan perbaikan kondisi dapur perlakuan panas model buka menjadi dapur perlakuan panas model tutup (Gambar 7) yang dilengkapi peralatan tambahan seperti: a) termokopel digital untuk mengukur temperatur hasil pembakaran arang kayu di dalam kowi, b) cerobong, dan c) blower dengan ventilator yang dapat diatur untuk mengatur kecepatan oksigen.

Hasil pelaksanaan uji komposisi kimia (Gambar 10) baja bekas komponen pegas daun SUP 9 milik pengrajin pande besi memiliki unsur $0,5818 \% \mathrm{C}$, sehingga termasuk jenis baja karbon menengah dengan unsur paduan $0,8878 \% \mathrm{Mn}, 0,8636 \% \mathrm{Cr}$ dan sisanya merupakan unsur pengotor (unsur ikutan) (Tabel 2). Baja karbon menengah mempunyai sifat mudah dibentuk melalui proses pemesinan, sifat kekerasannya lebih tinggi dibanding baja karbon rendah, mampu dikeraskan dan mampu ditempa seperti yang dilakukan pengrajin pande besi. Hasil pelaksanaan uji kekerasan (Gambar 11) pada baja bekas komponen pegas daun SUP 9 
milik pengrajin pande besi sebelum dan sesudah proses tempa panas setelah pendinginan cepat secara umum

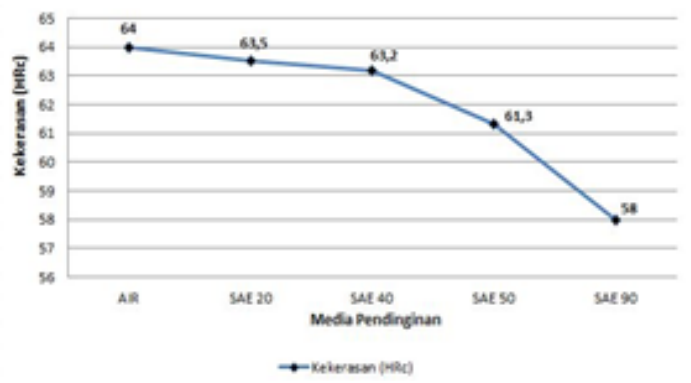

cenderung semakin menurun (Gambar 14).

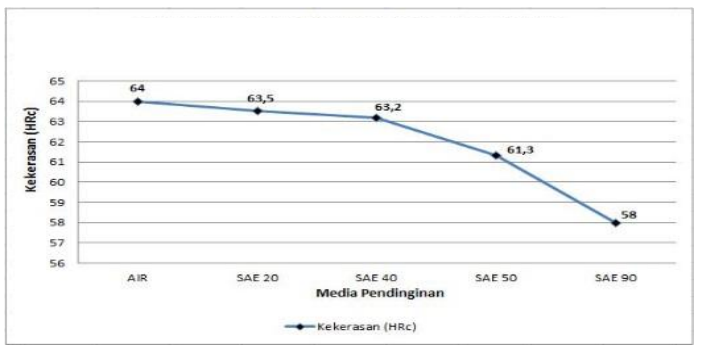

Gambar 14. Grafik Kekerasan $\left(\mathrm{HR}_{\mathrm{C}}\right)$ vs Variasi Media Pendinginan Cepat

Angka kekerasan sebelum tempa panas memiliki angka kekerasan $48 \mathrm{HR}_{\mathrm{C}}$ (Tabel 3) dengan fasa $\alpha$ lebih dominan yang sifat ulet tetapi kekerasannya rendah dibanding fasa $\alpha+\mathrm{Fe}_{3} \mathrm{C}$ sifat keras dan getas (Tabel 5) sesuai hasil uji pelaksanaan uji pengamatan struktur mikro (Gambar 13). Selanjutnya material tersebut, dilakukan proses tempa panas dengan temperatur $500{ }^{\circ} \mathrm{C}$ dan variasi media pendinginan air, oli SAE 20, oli SAE 40, oli SAE 50 dan oli SAE 90 mengalami peningkatan angka kekerasan tertinggi pada media pendinginan air mencapai $64 \mathrm{HR}_{\mathrm{C}}$ (Tabel 3 ) yang dipengaruhi pertumbuhan fasa $\alpha$ $+\mathrm{Fe}_{3} \mathrm{C}$ lebih dominan dibanding fasa $\alpha$ (Tabel 5) dengan laju keausan terendah mencapai $\quad 0.0000171975 \mathrm{gram} / \mathrm{m}$ sehingga sifat ketahanan ausnya tinggi. Angka kekerasan terendah pada media pendinginan oli SAE 90 mencapai 58 $\mathrm{HR}_{\mathrm{C}}$ (Tabel 3) dipengaruhi pertumbuhan fasa $\alpha$ lebih dominan dibanding fasa $\alpha+$ $\mathrm{Fe}_{3} \mathrm{C}$ (Tabel 5) atau angka kekerasan secara umum cenderung menurun yang dipengaruhi oleh kekentalan oli yang menghambatkan laju pendinginan (cooling rate). Angka kekerasan untuk produk cangkul untuk kelas 1 menurut SNI $55-59 \mathrm{HR}_{\mathrm{C}}$ (Tabel 3), sehingga hasil tempa panas dengan media pendinginan oli SAE 90 dengan angka kekerasan $58 \mathrm{HR}_{\mathrm{C}}$ (Tabel 3) memenuhi syarat SNI 02-0331-1989.

Hasil pelaksanaan uji keausan (Gambar 12) pada baja bekas komponen pegas daun SUP 9 milik pengrajin pande besi sebelum dan sesudah proses tempa panas setelah pendinginan cepat secara umum cenderung semakin meningkat, akibatnya sifat ketahanan ausnya semakin menurun (Gambar 15). Laju keausan hasil tempa panas baja bekas komponen pegas daun SUP 9, tertinggi pada media pendinginan oli SAE 90 mencapai $0.000165605 \mathrm{gram} / \mathrm{m}$ (Tabel 4), akibatnya sifat ketahanan ausnya rendah dan laju keausan hasil tempa panas terendah pada media pendinginan air mencapai $0.000105096 \mathrm{gram} / \mathrm{m}$ (Tabel 4), akibatnya sifat ketahanan ausnya tinggi. Laju keuasan yang paling rendah pada logam induk tanpa tempa panas mencapai $0.0000171975 \mathrm{gram} / \mathrm{m}$ (Tabel 4), sehingga sifat ketahanan 
ausnya sangat tinggi dibanding hasil tempa panas dengan variasi media pendinginan air, oli SAE 20, oli SAE 40, oli SAE 50 dan oli SAE 90.

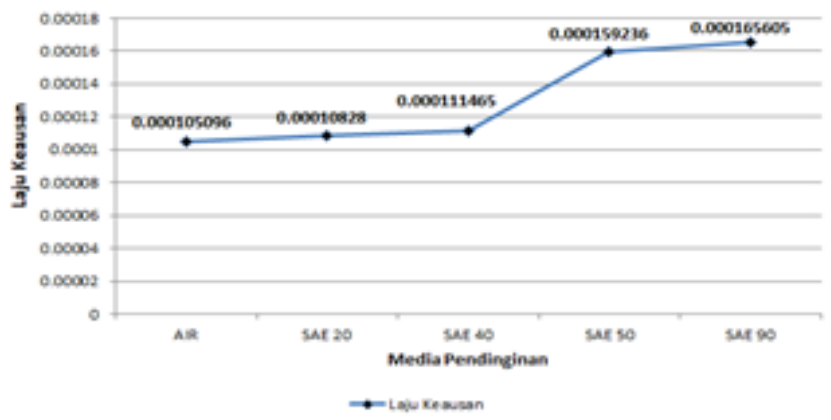

Gambar 15. Grafik Laju Keausan vs Variasi Media Pendinginan Cepat

\section{PENUTUP}

\section{Kesimpulan}

Angka kekerasan yang memenuhi syarat SNI 02-0331-1989 sebesar 58 $\mathrm{HR}_{\mathrm{C}}$ dan laju keausan 0.000165605 gram $/ \mathrm{m}$, sehingga sifat ketahanan ausnya rendah pada media pendinginan oli SAE 90 setelah penerapan desain dapur perlakuan panas model tutup.

\section{Saran}

Keberhasilan peningkatan kualitas produk pengrajin pande besi dengan penerapan desain dapur perlakuan panas model tutup dapat tercapai perlu adanya pendampingan dari pihak-pihak terkait yang berkelanjutan secara terprogram dan terstruktur.

\section{DAFTAR PUSTAKA}

Budi, E. 2011. Jurnal Fisika dan Aplikasinya, Volume XII Nomor 2 Desember 2011dengan judul "Pemanfaatan Briket Arang Tempurung Kelapa Sebagai Bahan Bakar Pengganti”

Chadwick, G.A., 1972. Metallography of Phase Transformation. London: Butterworth.
Dieter, G,E., 1981. Mechanical Metallurgy. Second Edition. Tokyo: McGraw-Hill International Book Company.

Eko Surojo, 2009. Pengaruh Manual Flame Hardening terhadap Kekerasan Hasil Tempa Baja Pegas" Jurnal Mekanika Volume 7 Nomor 2 Maret 2009. Halaman 45 -49 .

Esmar Budi, E. 2011.Jurnal Fisika dan Aplikasinya, Volume XII Nomor 2 Desember 2011dengan judul "Pemanfaatan Briket Arang Tempurung Kelapa Sebagai Bahan Bakar Pengganti” Fakultas Matematika dan Ilmu Pengetahuan Alam, Universitas Negeri Jakarta.

Furqon, M. 1997. Pengaruh Modifikasi pada Tungku Tradisional Pandai Besi terhadap Unjuk Kerja dan Produktivitas. Lomba Rancang Bangun Teknologi, BPPT.

Hamni, A. 2011. Jurnal Mechanical, Volume 2, Nomor 1, Maret 2011 dengan judul "Experimental Study Improvement Of Quality Of Hoe On Small Metal Industry In The Distric Pringsewu" Jurusan Teknik 
Mesin, Fakultas Teknik Universitas Lampung.

Iwan Setyadi, I. 2012. Jurnal Sains Materi Indonesia volume 14 Nomor 1 Oktober 2012 dengan judul "Analisis Pengaruh Teknologi Proses Produksi Terhadap Karakteristik Material Piston"

Iwan Setyadi. Analisis Pengaruh Teknologi Proses Produksi terhadap Karakteristik Material Piston" Jurnal Sains Materi Indonesia Volume 14 Nomor 1 Oktober 2012. Halaman 62- 66.

Jamilatun, S. 2008. Jurnal Rekayasa Proses, Volume. 2, Nomor. 2, 1 Maret 2008 dengan judul "SifatSifat Penyalaan dan Pembakaran Briket Biomassa, Briket Batubara dan Arang Kayu". Program Studi Teknik Kimia, Universitas Ahmad Dahlan Yogyakarta.
Setyadi, I. 2009. Jurnal Mekanika volume 7 Nomor 2 Maret 2009 dengan judul "Pengaruh Manual Flame Hardening Terhadap Kekerasan Hasil Tempa Baja Pegas"

Smith, W.F. 1990. Principles of Materials Science and Enginnering. Second Edition. McGraw-Hill International Editions.

Sugiyono, A. 2000. Pembuatan, Pemasangan dan Pengoperasian Tungku Perlakuan Panas. Direktorat Teknologi Konversi dan Konservasi Energi Deputi Bidang Teknologi Informasi, Energi, Material dan Lingkungan, BPPT.

Surdia, T. 1995. Pengetahuan Bahan Teknik. PT. Erlangga: Jakarta. 